Chen, L., Danbolt, J., and Holland, J. (2014) Rethinking bank business models: the role of intangibles. Accounting, Auditing and Accountability Journal, 27 (3). pp. 563-589. ISSN 1368-0668

Copyright (C) 2014 Emerald Group Publishing Limited

A copy can be downloaded for personal non-commercial research or study, without prior permission or charge

Content must not be changed in any way or reproduced in any format or medium without the formal permission of the copyright holder(s)

When referring to this work, full bibliographic details must be given

http://eprints.gla.ac.uk/87236

Deposited on: 31 March 2014

Enlighten - Research publications by members of the University of Glasgow http://eprints.gla.ac.uk 


\title{
Rethinking bank business models: the role of intangibles
}

\author{
Lei Chen, Jo Danbolt, and John Holland
}

Forthcoming in - The Accounting, Auditing \& Accountability Journal, 2014

\section{Purpose:}

This paper provides a new way of rethinking banking models by using qualitative research on intangibles.

This is required because the banking sector has been transformed significantly by the changing environment over the past two decades. The 2007-2009 financial crisis also added to concerns about existing bank business models.

\section{Design/Methodology approach:}

Using qualitative data collected from interviews with bank managers and analysts in the UK, this paper develops a grounded theory of bank intangibles.

\section{Findings:}

The model reveals how intangibles and tangible/financial resources interact in the bank value creation process, how they actively respond to environmental changes, how bank intangibles are understood by external observers such as analysts, and how bankers and analysts differ in their views.

\section{Research implications:}

Grounded theory provides the means to further develop bank models as business models and theoretical models. This provides the means to think beyond conventional finance constructs and to relate bank models to a wider theoretical literature concerning intellectual capital, organisational and social systems theory, and 'performativity'.

\section{Practical implications:}

Such development of bank models and of a systems perspective is critical to the understanding of banks by bankers, by observers and for their 'critical and reflexive performativity’. It also has implications for systemic risk and bank regulation.

\section{Social implications:}

Improvement in bank models and their use in open and transparent processes are key means to improve public accountability of banks.

\section{Originality:}

The paper reveals the core role of intellectual capital (IC) in banks, in markets, and in developing theory and research at firm and system levels.

Key words: bank models, knowledge, intermediation, external observers, systems. 


\section{Introduction}

Banks play an important role in resource allocation by transferring funds from those in surplus (depositors) to those in deficit (borrowers) (Berger et al., 2010). Traditional theoretical models of banks as financial intermediaries indicate that they help in reducing the friction of transaction costs (e.g., Benston and Smith, 1976) and information asymmetry by acting as delegated monitors between lenders and borrowers (e.g., Diamond, 1984).

In recent years, banking systems have experienced significant transformations driven by deregulation, technological change and the globalisation of goods and financial markets (Berger et al., 2010; Wilson et al., 2010), and bank activities have been largely altered as well. The importance of the conventional functions of taking deposits and making loans for banks has been reduced. Banks now tend to perform more sophisticated functions in the modern economy, such as risk management (Scholtens and van Wensveen, 2000), and have developed various business models in response to the increasing competition. According to IIRC (2011:1), business model is defined as “the organization's chosen system of inputs, business activities, outputs and outcomes that aims to create value over the short, medium and long term”. In these terms, bank business models consist of many integrated, interacting elements designed for value creation and matched to their competitive environment (Porter, 1985). These bank business models seemed to work well, at least until the middle of 2007. However, the financial crisis that occurred in 2007 has led to academics and policy makers expressing concerns about the new banking business models. Wilson et al. (2010: 154) suggest that it is necessary to re-examine "the scale, scope, governance, performance and the safety and soundness of financial institutions”.

There has been a large amount of research investigating how bank-specific, industry-specific and macroeconomic factors may have impact on bank performance (e.g., Athanasoglou et al., 2008; Dietrich and Wanzenried, 2011). However, the literature on bank strategies and performance appears to be somewhat limited, as it focuses heavily on tangible or financial resources in banks. The world economy has moved from an industrial economy to a knowledge-driven economy (Meritum, 2002), and wealth and growth are now "driven primarily by intangible (intellectual) assets" (Lev, 2001: 1). As an intellectually intensive sector, intangibles tend to be extremely important for banks. 
Against this background, we conduct a qualitative study investigating how intangibles affect bank intermediation, value creation, and performance. We explore how banks use their understanding of intangibles to improve information disclosure to the market, and how analysts understand and use this information in different ways. We offer suggestions as to how bank business models and the role of bank intangibles should be rethought.

This paper makes contributions to both the banking and intangibles literatures. First, distinct from the majority of empirical research that has looked at the impacts of tangible or financial assets on bank performance, this paper adopts a wider approach to the investigation of banks’ value creation processes by taking into consideration both intangibles and tangibles. The grounded theory generated from interview data offers insights into the value creation process in banks, showing how the integration of intangible resources and tangible/financial resources provides the means to improve financial and information intermediation processes as well as risk management in banks. It is also helpful in facilitating ways for bank managers to measure and manage their intangibles more effectively. In this sense, this research provides novel ideas on how bank business models can be improved. Second, the above provides the means to explore how theoretical models of banks can be further developed to include more explicit ideas of intangibles in intermediation, in resolving information problems and in risk management.

Third, the extant literature on intangibles focuses on the investigation of either organisation managers' perspectives or the capital market actors', and empirical evidence on the latter tends to be embryonic. This paper contributes to the literature by exploring the perceptions of both bank managers and analysts on intangibles measurement, disclosure and modelling. By so doing, we are likely to provide a more comprehensive picture of intangibles than previous research, and are able to show the communication gap between these two groups of people. The bank and analyst nexus and issues of bank intellectual capital (IC) and value creation are discussed within the wider network of the 'market for information'. The latter is interpreted within the actor-network theory (Latour, 1993) and Henningsson’s (2009) insights into the social forces effecting actors in financial markets. The performative role (Mackenzie and Millo, 2003) of bank models (business and theoretical) and other knowledge constructs in the information market network is also recognised. This view and the 
need for wider shared understanding of banks, places the empirical findings and the call for new bank models in a novel theoretical context.

The remainder of the paper is structured as follows. Section Two provides a review of relevant theory and literature. Section Three outlines the data collection and data analysis processes of the paper and the empirical results are presented in Section Four. Section Five discusses the implications of the findings for existing bank models and for observers in external markets. Finally, the conclusions are discussed in Section Six.

\section{Theory and literature review}

While both tangible and intangible resources can be potential strategic assets, empirical research shows that tangible resources are transparent and relatively easily duplicated, and intangible resources ${ }^{1}$ are normally the key strategic resources in a firm (e.g., Fahy, 2000). Intellectual capital (IC) is commonly categorised into human capital (HC), structural capital (SC) and relational capital (RC) (Meritum, 2002), and the three components of corporate knowledge are expected to interact with each other and then contribute to a firm's superior performance (Reed et al., 2006). However, empirical evidence of relationships among different intangible elements and between them and firm performance tends to be limited. Because of the inherent unobservability of intangibles, it is difficult to measure them in quantitative terms and compare them across companies. Consequently, the level of intangible disclosure across countries or sectors tends to be very low (Beattie and Thomson, 2007), and the remaining information asymmetry related to intangibles is still high (Holland, 2009).

Because of the problems with intangible measurement and disclosure, quantitative research tends to be limited. There have been calls for more quantitative evidence of modelling intangibles, as research on intangibles has to be improved by testing (Marr et al., 2003). However, this research notes that apart from problems with intangible measurement and disclosure, the complexity of the value creation model of intangibles also prevents academics from providing quantitative empirical evidence of the impact of intangibles on firm performance.

\footnotetext{
${ }^{1}$ Although the intangibles literature has developed over several decades, research dealing with intangibles suffers from a fundamental problem, which is the lack of common terminology (Kristand and Bontis, 2007). Different terms have been used in reference to intangible assets, such as intangibles, intellectual capital or knowledge assets (Beattie and Thomson, 2007; Lev, 2001). In this paper, following Lev's (2001) and Meritum's (2002) argument, the terms intangible resources, intangibles and intellectual capital are used interchangeably.
} 
Some researchers have tried to explore the interactions between different intangible elements and bank performance by conducting qualitative case studies (e.g., Cuganesan, 2005; Holland, 2004; Johanson et al., 2001; Murthy and Mouritsen, 2011). Their findings show that there are various forms of interactions and transformations among different elements of intangibles rather than simple linear cause-and-effect relations between individual intangible elements and performance. For example, Cuganesan (2005) finds that different components of intangibles transform each other often in a pluralistic and fluid manner in a financial firm.

The complexity of the value creation model of intangibles is reflected in not only the interrelationships among different intangible components, but also their interactions with tangible or financial assets. Murthy and Mouritsen (2011) argue that IC in the form of competences is based on complementarities between bank HC, SC and RC, and only exists during their joint performance. They explore the relationship between IC elements and financial capital via an interview-based case study in a bank, and find that financial capital is not only an effect but also an important input for IC, because IC has to be developed through the firm's budgeting process, and the budget may reduce the relationships between IC elements.

It can be seen that the value creation process of intangibles is complex and dynamic, and a better understanding of the relationships among intangible elements and between them and firm performance will help researchers to model intangibles in bank business models in a more appropriate way. This paper recognises the need for more qualitative research to complement the proposed quantitative work. Generation of grounded theory is one means to advance research on both qualitative and quantitative dimensions of value creation, hence providing a more adaptive and flexible conceptual frame for bank decision makers and external observers.

Especially, this paper argues that there is scope for in-depth qualitative empirical research in this regard in the banking sector. The banking sector is chosen as the research context because of the importance of intangibles to banks' business model and limited literature on banks’ knowledge based intangibles.

Over the past several decades, the banking sector experienced major changes, such as deregulation, technological development, and globalisation, which dramatically altered banks’ competitive environment. Enhanced competition has forced banks to explore resources that could lead to business success. In the banking sector, where banks provide similar financial intermediation and payment services, and where 
publicly observable bank products have the characteristics of being easy to copy and lacking in adequate patent protection (Watkins, 2000), intangibles tend to be fundamental to creating competitive advantage for banks.

However, literature on how well the bank business model is run has focused heavily on tangible or financial resources in banks such as capital and bank size (e.g., Athanasoglou et al., 2008; Dietrich and Wanzenried, 2011), but paid little attention to the investigation of how banks exploit their intangible resources in a knowledgedriven economy, with the exception of Holland (2010).

Holland (2010) discusses the central role of IC or knowledge based intangible resources in banking, where IC comprised three elements: HC, SC and RC (Meritum, 2002; Mouritsen et al., 2002). Knowledge based intangibles and their impact on tangibles (especially intermediation mechanisms and financial resources) are the primary source of sustainable competitive advantage in banking. A bank's sustainable competitive advantage comes from not only strategic resources that the bank has, but also dynamic capabilities that adapt to the changing environment (e.g., Teece, 2007; Teece et al., 1997).

Moreover, previous interview-based case studies that investigated how organisations measured, managed and reported intangibles tend to focus either on internal managers' perspectives (e.g., Beattie and Thomson, 2010; Johanson et al., 2001) or market actors' perspectives (e.g., Abhayawansa, and Abeysekera, 2009; Abhayawansa and Guthrie, 2012; Campbell and Slack, 2008; Henningsson, 2009; Holland, 2006; and Holland et al., 2012), and evidence on the capital market actors' perspectives on intangibles is embryonic.

Holland's (2006) study provides evidence of the importance of intangible information to capital market actors. He finds that fund managers faced major problems in their investment decisions because of the increasing importance of company intangibles to share price, and the limitations of public information. They used private meetings with company management to obtain information about intangibles and to understand the dynamic connections between intangible variables in the value creation process.

However, Campbell and Slack's (2008) findings contradict this. Campbell and Slack (2008) explore the usefulness and materiality of annual report narrative disclosure in the UK, with particular reference to the banking sector. They observe 
that the narrative parts of annual reports that normally contain information about banks' intangibles tend to be relatively unimportant to analysts.

Abhayawansa and Abeysekera (2009) investigate IC disclosure by sell-side analysts. They noted that IC information disclosed by analysts cannot be taken at face value. Using an original theoretical framework, they argue that issues of signalling, analysts' incentives/influences, political economy view and globalisation have to be employed to explain IC disclosure in sell-side analysts' reports. Abhayawansa and Guthrie (2012: 398) develop these ideas further using an "impression management" frame. Noting conflicting interests facing analysts and the relative amenability of IC information, they find that analysts used IC information to manage perceptions. Analysts used IC information to "subdue the pessimism associated with an unfavourable recommendation, increase credibility of favourable recommendations and distinguish sell from hold recommendations” (Abhayawansa and Guthrie, 2012: 398).

This paper aims to investigate the role of intangibles in the bank business model using interviews with both bank managers and analysts. We explore the variation in views on intangibles from different groups of people, thus providing a more comprehensive picture of the role of intangibles than previous interview-based case studies. In particular, we are interested in how different intangibles interact with each other and integrate with tangible or financial assets in value creation, in intermediation, and performance in banks. We are interested in how banks use this enhanced understanding of intangibles to improve information disclosure to the market, and how analysts understand and use this information in the same or different ways.

\section{Methodology}

\subsection{Data collection}

Given the research purpose of investigating the role of intangibles in the bank business model, senior managers (e.g., CEOs, CFOs or directors of retail or commercial banking) in UK financial institutions, as well as analysts who specialise in the banking sector, were targeted for interviews. Senior level managers were considered to be those who had broad knowledge about their organisation's strategies, policies and business practices, and were expected to understand the research problem better than low level management and employees. Similarly, analysts who specialise 
in the banking sector were chosen to be another set of interviewees on the grounds that they were considered to be experts with specialist knowledge and understanding of bank valuation.

The fieldwork was undertaken between June 2008 and September 2009, during which time the global financial crisis occurred. It should be noted that, although the financial crisis created difficulties in accessing the targeted interviewees, it was helpful to the research because managers and analysts could reflect on how intangibles played a role in bank performance and value under quite different circumstances. This stimulated 'theoretical sensitivity' and the search for variation in core concepts.

Twelve interviews with bank analysts and eleven interviews with senior managers in financial institutions were conducted. The majority were one-to-one interviews, with the exception of one interview in which two bank managers participated. The interviews lasted from fifteen minutes to one hour and twenty minutes. Six were telephone interviews, while all others were face-to-face interviews conducted at the case organisations. With the interviewees' permission, eighteen interviews were audio-recorded and then transcribed carefully in order to provide a basis for reliable data analysis.

The interview questions were designed to be semi-structured in order to encourage participants to talk freely and openly about their opinions and experience. Interview guides were constructed based on four specific questions:

- What may be the important intangibles for a bank?

- How do they relate to bank performance?

- How can these intangibles be measured?

- How have these intangibles been reported?

The interview guides served as a reminder and were used flexibly to probe issues such as interactions between intangibles. After each interview, the researchers reviewed the interview process, and revised the interview guides based on gained information. Notes were taken by the researchers during each interview, regardless of whether it was recorded or not. The transcripts or notes of the interviews were sent back to the participants to get their feedback and to check the accuracy of the data.

\subsection{Data analysis}


The interview data was processed by adopting a grounded theory method, using "a systematic set of procedures to develop and inductively derive grounded theory about a phenomenon” (Strauss and Corbin, 1998: 24). Combining this technique with a case study has the potential to strengthen case analysis by searching for patterns through cross-case analysis (Parker and Roffey, 1997). Moreover, the clearly specified operational procedures of grounded theory data analysis can enhance construct validity of a qualitative study (Pandit, 1996).

Based on previous work by, among others, Beattie et al. (2001), Locke (2001), Parker and Roffey (1997) and Strauss and Corbin (1998), the interview data was analysed through five stages: familiarisation, reflection, open coding, axial coding and selective coding. All the case data was manually analysed due to the consideration that grounded theory is an "interpretive process" (Suddaby, 2006: 638) between the researcher and the data, and the researchers' theoretical sensitivity tended to be very important in all stages. Enhanced theoretical sensitivity helped the researchers to challenge their existing assumptions and knowledge structure and move from description to theoretical analysis.

As the initial stage of data analysis, familiarisation with interview data started in the data collection process. The researchers transcribed each interview immediately after it was conducted and generated a record of 'big ideas' or tentative broad concept categories for each interview. At the stage of reflection, the researchers undertook some preliminary cross-case analyses by comparing and critically evaluating individual case data with other cases as well as previous literature. Similarities and differences among some important issues were grasped, and were recorded in theoretical memos. Memos that recorded the researchers' early thoughts, memories and reflections with the case data (such as code notes of 'big ideas' and theoretical memos) facilitated further systematic coding, and were continuously used throughout the entire process of data analysis.

Subsequent to the reflection stage, the researchers went through each case interview line by line in the open coding stage. The transcripts and notes were read carefully in order to find key words or phrases, and names or labels were given to them. Then a code card was constructed, and the labelled code was written on it. Once the same concept was identified in other case interviews, it was added to the earlier constructed code card, with the case number and page number being indicated. Then concepts with similar characteristics were grouped to develop categories and subcategories. 
Corresponding to the literature on intellectual capital, four main categories related to intangibles were identified in this process, namely 'top management human capital (HC)', 'employee level human capital (HC)', 'structural capital (SC)' and 'relational capital (RC)'.

Axial coding is the process of establishing linkages among categories and subcategories (Strauss and Corbin, 1998). The technique of constant comparison was used in order to test the established relationships against data. Specifically, the linkages among concepts and the four main categories were identified, and a new, large category was formed, namely 'interactions'. This macro category was further developed into three core codes: 'intra-category interactions', 'cross-category interactions' and 'network interactions'. It should be noted that although axial coding differs from open coding in terms of purpose and procedure, they sometimes happened contemporaneously in this study.

In the final step of selective coding, the focal core code, that is, the central category for theory integration (Parker and Roffey, 1997), was selected, and other categories were linked to it. In this case, the core category was the macro category of 'interactions' developed in the axial coding process. Surrounding it, other major codes were grouped into two broad conceptual categories: 'conditions' and 'consequences'. By linking those categories to the central category, a theoretical framework of banking intangibles was developed.

\section{Empirical results: a grounded theory of bank intangibles}

\subsection{Overview of the grounded theory of bank intangibles}

The grounded theory of bank intangibles was developed from case interviews with both bank managers and analysts. Similarities and differences in bank managers' and analysts' views on intangibles, were rich and valuable information sources about the role of intangibles in the bank business model and in the development of a grounded theory of bank intangibles. The latter revealed that under certain conditions, intangibles integrated with other types of resources through three different levels, namely intra-category interactions, cross-category interactions and network interactions, and then affected institution performance and information disclosure. Figure 1 presents the overall grounded theory of bank intangibles.

Insert Figure 1 about here 
It can be seen from Figure 1 that the combinations and interactions of intangibles and tangibles formed the core of the grounded theory. Tangibles provided the foundation upon which intangibles, as the key sources of competitive advantage, could have an impact. The interactions among intangibles could be either intracategory interactions or cross-category interactions. The former occurred between intangibles in the same category, while the latter were interactions among intangibles in different categories. The intangibles affected tangibles and created value through the process of internal bank network interactions, such as reducing transaction costs, improving the intermediation process and risk management. Such combinations and interactions of resources finally affected the financial performance, value and information disclosure of the financial institution, as indicated under 'consequences' on the right of the flowchart. Table 1 provides some examples of interactions identified in the case data.

\section{Insert Table 1 about here}

All the above combinations and interactions of intangibles and tangibles were adjusted under certain conditions. Those conditions, as presented on the left side of Figure 1, included multiple (and possibly interacting) causal conditions and contextual conditions. Causal conditions that were mediated by contextual conditions continued to influence the role of intangibles in the bank value creation process.

In addition, it was found that the value creation process was an ongoing feedback and learning process for the case institutions, as shown at the bottom of the picture. Top management in the case institutions continued to learn from broad interactions of conditions, intangibles, tangibles and consequences. They gained experience and knowledge in identifying and developing key sources of competitive advantage and setting up coherent strategies to search for the appropriate combination of intangibles and tangibles in response to conditional changes. These findings provide evidence in support of the argument of dynamic capabilities, which suggests that resources and dynamic capabilities are closely interlinked in exploring firm competitive advantage (Teece, 2007).

The learning and changes in the bank were also drivers for learning by analysts about bank IC and its changing role in bank value creation and value. This revealed a longer term dynamic dimension to grounded theory, both in the bank and in its external network. 
The key interactions and combinations included intra IC category interactions, the inter IC category interactions, internal firm network interactions, the contingent nature of the IC combinations relative to external change, the special combinations for business segments, and the feedback and learning leading to new IC. These interactions and combinations show elements of linearity, non-linearity (two-way and multiple causality), variety and transience in the interactions between different intangible elements and bank performance. This is consistent with prior work by Johanson et al. (2001), Holland (2004), Cuganesan (2005) and Murthy and Mouritsen (2011). These interrelationships were more complicated and dynamic than simple linear models. However, these findings were consistent across the case banks, revealing the potential for further development of bank models. In particular, it revealed the potential (as discussed in section 5 below) for developing theoretical models by using empirical findings such as the grounded theory, IC literature, and Weick’s (1979) view of organisations as interactive systems, to adapt conventional financial concepts of banks.

\subsection{Conditions}

Corresponding to grounded theory terms, conditions in this study included causal and contextual conditions. The causal conditions were changes in the external environment, including changes in the economic environment (e.g., financial crisis) and in the banking industry (e.g., business globalisation and technology development). Contextual conditions consisted of the industry context (e.g., industry characteristics and business segment characteristics), regulatory and standard setting, and special conditions such as merger and acquisition (M\&A) activity.

Almost all the interviewees, both analysts and managers, discussed how changes in the economic environment influenced the role of intangibles in the financial institutions. Ongoing economic change, especially the global financial crisis in 20072009, not only influenced financial institution strategies in terms of making use of the interactions among intangibles, but also changed the market perception with respect to understanding intangibles in the banking sector. For example, customer relationships were argued to be a core intangible element for many case institutions. Good customer relationships became even more important during the financial crisis in 
terms of helping banks to maintain and further increase their customer deposits and capital. As analyst $\mathrm{A} 5^{2}$ argued,

"[N]ow when all the consumers and general public are very nervous about their bank, I think it becomes more important than ever that you have a strong customer franchise."

Changes in the banking industry also influenced the elements of intangibles and institutions' strategies for them. Technology development has significantly changed the competitive environment in which banks operate. New technology created opportunities for them to reduce costs and deliver products and services through different channels, and for improved intangible management. On the other hand, technology development provided more choices to customers in terms of bank products and services, and hence increased the difficulty of maintaining customer relationships for banks. Moreover, business globalisation was also an important factor that drove the interactions among intangibles in the case institutions. The globalisation of banking endowed some intangible elements with new meanings. For example, manager B7 argued that the consistency of the brand in different countries became an important intangible for them.

Contextual conditions refer to the general conditions within which the interactions take place (Dey, 1999). A variety of contextual conditions have been identified from the case data; among them, the industry context, which includes various industry characteristics and business segment characteristics, was mentioned by most interviewees. For instance, customer inertia was argued to be an important factor affecting customer relationship management ${ }^{3}$. On the one hand, customer inertia made it easy for the case banks to retain existing customers. On the other hand, customer inertia was an obstacle to attracting new customers. Analyst A3 mentioned that as there was so much customer inertia in the UK banking sector, even if a bank provided very attractive current account offer, it was difficult for it to increase market share.

Apart from industry characteristics, characteristics of business segments were suggested to also be contextual conditions that influenced intangibles in terms of the

\footnotetext{
${ }^{2}$ For the case code, A1 to A12 refer to interviews with bank analysts, and B1 to B11 to interviews with managers in the case institutions.

${ }^{3}$ Previous literature suggests that there appears to be inherent customer inertia in the banking sector; that is, even if a customer is dissatisfied with his/her bank, he/she may not change bank in the next year (Colgate and Danaher, 2000).
} 
relative importance of different intangible elements, the interactions, and bank strategies in managing intangibles. Core intangibles tended to vary in different business segments. The case institutions, therefore, had to set different strategies in response to the variation in the role of intangibles. For example, manager B4 argued that service quality was relatively more important in private banking than retail banking. Therefore, as a private banking manager, he preferred to allocate more resources to human capital aspects than to other intangibles.

Besides, it was found that the external regulatory climate appeared to be an important conditional feature that had bearing upon the role of intangibles. Some interviewees discussed the influence of regulations (such as the regulatory response to the 2007-2009 financial crisis and the principle of Treating Customers Fairly ${ }^{4}$ ) or accounting standards on intangibles. Special conditions for financial institutions, such as M\&A activity, could also lead to changes in their intangibles strategies. For instance, human capital tended to be the core intangible in the M\&A context, and the interactions between human capital and customer relationships became even more critical during the process of integration.

\subsection{Interactions}

The core category in the grounded theory of intangibles was the interactions. The first level of interactions, namely intra-category interactions, referred to the relationships between different concepts that were grouped in the same category. It basically involved the relationship between intangible investments and intangible resources. Meritum (2002) suggests that different intangibles can be classified into intangible resources and intangible activities, according to their static or dynamic character. The former can be considered as assets in a broad sense, while the latter are activities that might give rise to new intangible resources or improve the value of existing ones. The case data revealed that, in practice, banks were concerned about not only the critical intangible resources that they had but also the activities that could lead to an increase or decrease in these resources. For example, the bank manager in

\footnotetext{
${ }^{4}$ Treating Customers Fairly (TCF) is encapsulated by Principle 6 of the Financial Services Authority's (FSA) 11 Principles for Businesses. TCF aims to balance the customer's needs with the firm's needs, showing clearly what the firm and its services offer, as well as fees and levels of service (Speech by Sam Tymms, 19 May 2006, available at:

http://www.fsa.gov.uk/pages/Library/Communication/Speeches/2006/0519_st.shtml,accessed on 2 February, 2011)
} 
interview B5 (see Table 1) pointed out that training investment (employee level HC investment) was associated with employee satisfaction (employee level HC resource).

Intra-category interactions also consisted of relationships among different intangible resources in the same category. For example, many interviewees, both managers and analysts, emphasised that brands tended to be closely related to customer relationships. As manager B11 argued, "the value of the brand is attracting customers”.

Cross-category interactions, as the second level of interactions in the value creation process, revealed how different intangible elements interacted with each other across the four main IC categories. Many managers and analysts interviewed demonstrated that top management HC appeared to lie at the heart of cross-category interactions, as it could influence many other types of intangibles (e.g., organisational culture and its 'tone', engagement of lower level managers and employees, customer relationships and bank brands). For example, analyst A6 (see Table 1) stated that,

"[T] he idea from an analyst... is [that] the management will set the tone on the culture and a lot of other intangibles, and therefore they are the starting point for all of those."

In addition, cross-category interactions involved how employee level HC and RC interacted with each other, and how they combined with SC to contribute to the bank value creation process. On the one hand, front line employees or relationship managers who had direct contact with customers could affect RC elements such as customer satisfaction or customer relationships. On the other hand, RC could also affect employee level HC. For example, manager B4 (see Table 1) mentioned that their brand strength (RC) could enhance employee emotional capital (employee level HC as commitment). Manager B7 provided an example of the interactions among SC, employee level HC and RC, as shown in Figure 2.

Insert Figure 2 about here

More importantly, the case data showed that the interactions across various categories of intangibles were complicated, as they were normally interconnected and could not create value in isolation. Manager B8 argued that

“...if I didn't have the structural capital in place, I wouldn't be able to afford to give customer a good experience... And if I didn't have good people, they wouldn't invent the structural capital to do that." 
The third level of interactions, namely internal bank network interactions, consisted of the interactions between intangibles and tangibles, such as the impact of say top management human capital on financial intermediation, financial resources and risk management mechanisms. Managers in banks recognised there was a two-way relationship between intangibles and tangibles. Tangibles acted as the hygiene or necessary factors, which provided the foundation for the bank business model to work As manager B5 stressed, 'playing a brand card' can produce significant incremental revenue or profitability only if the products or services are at least at certain hygiene level.

Simultaneously, intangibles interacted with tangibles and financial resources during the process of internal bank network interactions, and influenced financial intermediation activities and risk management. They provided the means to reduce transaction costs, to make the intermediation process and risk management more effective, and also to optimise the deposit or loan portfolio. Specifically, on the liability side of the balance sheet, intangibles, such as brand strength and customer emotional capital, played a critical role in attracting deposits, especially during the financial crisis. On the asset side of the balance sheet, relational capital could influence lending activity and the selling of other products. Moreover, in line with prior research (e.g., Holland, 2010), the case interviews provided evidence of the importance of intangibles in reducing transaction costs and improving risk management, such as reducing deposit withdrawal risk and controlling bad debt risk. For example, manager B8 explained how their brand strength (relational capital) helped them to reduce the cost per account (i.e., the cost for them to get a new customer), while manager B1 noted that employee level HC, particularly experienced agents, had the ability to better control cost, bad debt risk and manage their customer base than new agents.

The interactions discussed above lie at the heart of the grounded theory, and the combination of them leads to the consequences, which is discussed in the next subsection.

\subsection{Consequences}

The consequences of interactions were related to both bank performance and information disclosure in the external market. The discussion of network interactions has clearly offered illustrations of the first consequence. It can be seen that the 
interactions of intangible strengths and other types of resources could lead to an increase in deposits or loans and a reduction in cost and risk, and these could result in better institutional performance. Improved performance could come from individual intangible strengths. For example, a high level of management skills or customer recommendation score could be directly associated with better bank performance. Most importantly, however, the combined effects of different intangible resources and other types of resources were more significant than individual intangible strengths. In this manner, the three levels of interactions should be jointly managed and exploited to maximise their impact on firm performance. It is the role of top management to develop a coherent strategy to identify the appropriate combination of different types of key resources in order to deliver superior performance.

The second consequence, that is, the intangible disclosure to the information market, is discussed in the next subsection.

\subsection{Understanding IC based intangibles from managers' and analysts' perspectives}

\section{- A view from the 'market for information'}

The empirical results also showed that the managers and analysts interviewed presented different views on general ideas related to intangibles, including the definition of intangibles, the importance of intangibles to bank business success and the key intangible elements or indicators. As a result, the internal management and external observers (bank analysts) had different views on the dominant intangibles and processes outlined in the grounded theory and on bank (and analyst) disclosure of IC based information to the external world.

Managers interviewed were more likely to be comfortable with the definition and classification of intangibles in academic research than analysts. Managers perceived intangibles to be a broad concept that included not only the accounting number of goodwill and other intangible assets on the balance sheet but also other non-financial items, while many analysts appeared to focus mainly on the former when they talked about the term intangibles.

Almost all the managers interviewed presented the view that intangibles rather than tangibles were key sources of competitive advantage for their institutions. The analysts' views on the importance of intangibles, however, appeared to differ from managers'. It is found that although analysts acknowledged the significance of intangibles in wealth creation, they prioritised tangible or financial strengths rather 
than intangibles in contributing to superior bank performance, especially during the financial crisis. The reasons for these differences were presumed to be related to the different tasks and organisational social context of these actors and are discussed in Section 5.3 on implications.

A difference was also observed in views of the key intangible elements. Interviews with managers showed that most of the case institutions had relative strengths in some intangibles over others. Some managers highlighted the importance of balancing or combining different types of intangibles, although at the same time they paid more attention to the intangible elements in which they had relative strengths compared with rivals. For example, on the one hand, manager B8 pointed out that culture was the No.1 intangibles for them as the culture in their bank was "unique" from peer group. On the other hand, he highlighted that,

"I think it's a combination of all three [human capital, structural capital and relational capital]. ...I don't believe in those companies that only focus on relational capital, because it is very nice to have very loyal customers, but if your business model is too expensive, you can't make money. ...you have to do all three, clearly."

Others emphasised the specific intangible strengths they had or their critical intangible items at the time of the financial crisis. It should be pointed out that apart from intangible strengths that have been developed historically, some specific intangible elements (e.g., customer relationships, brands and HC) became relatively more important due to the change in economic environment, in particular the financial crisis.

In contrast to the view of managers, the majority of analysts interviewed indicated that goodwill on the balance sheet and top management HC were the most important intangible elements for banks. For example, analyst A3 argued that apart from goodwill, "the management is the only area what people think is valuable source of intangibles within a bank”. One possible reason of prioritization of goodwill and top management quality by analysts may be that they had better access to these two types of intangibles compared with other intangible elements. Bank managers are closer to bank intangibles than analysts, and thus they may understand the importance of the broad set of intangibles better than analysts.

Limited access to intangible information tended to narrow analysts' understandings of intangibles, reflecting Holland and Johanson's (2003) view of communication barriers. However, consistent with Abhayawansa and Abeysekera (2009), 
Abhayawansa and Guthrie (2012), Henningsson (2009) and Holland et al. (2012) (but inconsistent with the findings of Campbell and Slack (2008)), we found that intangibles were important to the analysts interviewed. However, there appeared to be a difference between bank analysts' public reports and their private thinking. Even if analysts could not put information about intangibles in their public reports, they thought about it privately and commented on it when they communicated with their clients.

There were also important differences between bank disclosure activity and analysts' views of this disclosure. We found that there was a communication gap between sell-side analysts, who were considered one of the primary users of accounting information, and managers, who acted as providers of intangible information. Such a situation is illustrated by Figure 3 .

Insert Figure 3 about here

Figure 3 shows that managers in the case institutions tended to provide forwardlooking explanations of the value creation process by using information about intangibles, while analysts looked at intangibles through a reverse attribution or inference of financial performance (FP) to intangibles.

The grounded theory of bank intangibles suggested that intangibles were linked resources or activities, and measures of them were expected to reflect the inherent dimensions and properties of value creation factors or intangible elements. However, the case data showed that because intangibles had a highly subjective, socially constructed dimension, measuring them quantitatively was difficult. In addition, some managers (e.g., manager B2) argued that it was risky to quantitatively measure intangibles because there was a danger that the quantitative numbers might not appropriately capture the inherent dimensions of intangibles, and hence might fail to facilitate management decision-making.

The case institutions were generally advanced in measuring their key intangibles, and some of them have developed systematic measurement frameworks, normally the Balanced Scorecard (BSC). Nevertheless, many intangibles were still evaluated in qualitative terms rather than in numbers, and most of the case institutions were in the process of describing distinct intangible elements, but paid little attention to measuring the outcomes of them.

Because of these difficulties with intangible measurement, most of the disclosed intangible information in the market is in qualitative manner. However, analysts 
expressed an increasing need for quantitative information about intangibles and the linkage between them and institution financial performance. These kinds of information were valuable for them to explain or predict the value creation process and crucial factors that create superior financial performance in banks. For example, analyst A 10 expressed a keen interest in intangibles "if I can see a monetary issue attached with it and a way to prove it".

Analysts prefer to present themselves publically as logical, numerate, and 'scientific'. They prefer to disclose less 'soft' information, and less difficult to measure company IC information in their public reports. This bias and impression management corresponds to research by Chan et al., (2007); Mehran and Stulz, (2007), Abhayawansa and Abeysekera (2009), and Abhayawansa and Guthrie (2012). However, they may use private access to companies to acquire new information on company IC (e.g., private meetings with bank managers and managers' track records), especially outlier information that deviates from the consensus. They may use this to report in private to clients such as fund managers, to trade on their own behalf (in investment bank parents) or to trade information with competitor companies. Thus, analysts can 'present' or 'perform' (Mackenzie and Millo, 2003) one idea of company IC in public and another in private. Both have wider impacts in the information market networks through exchange mechanisms.

Given the fact that the bank managers did not reach the stage of fully matching intangible measures with their value creation story, the analysts had to use not only intangible information but also their experiences over time to explain the value creation process or predict bank value. As analyst A6 said,

“...one of the things I'd like to do is to look at the change of return on assets over five years or ten years, and then to see which bank management is adding the most value. Now in a way that's tangible, but ... you have to assume that there are intangible elements driving [it]."

Moreover, managers appeared to be reluctant to report detailed information about intangibles, and this seemed to further deepen the communication gap between them and analysts. Intangibles were key sources of competitive advantage, and information about them was commercially sensitive for the case institutions. Many interviewees also expressed concerns regarding the reliability, auditability and comparability of intangible measures that they used. Analysts found that it was difficult for them to get reliable information about intangibles to assist in their bank valuation. 
Therefore, it can be seen that appropriate intangible measurement, management and disclosure are not only critical for bank managers, but also very important for observers such as analysts in the financial markets. In the next section, these measurement, communication and disclosure problems and differences between bankers and analysts are discussed relative to Henningsson's (2009) view that external observers such as analysts and fund managers are 'cultured observers' of companies (such as banks) and their IC information.

\section{Theoretical discussion and implications of the paper}

This section explores implications of the research for improving bank business models and theoretical models. It also considers the wider system implications of such improvements for wider external understanding of bank models by observers such as analysts and for this to potentially reduce systemic risk possibilities.

\subsection{Implications for understanding banks and improving their business models}

The empirical significance of the grounded theory research is it provides a means to search for ways to rethink bank business models. At the bank level, the grounded theory shows that an appropriate combination of knowledge based intangibles and tangibles allows a bank to create value, inter alia, by reducing transaction costs, optimising its deposit and loan portfolio, and improving the intermediation process and risk management. Therefore, bank managers should be able to develop their business model by balancing different types of resources and exploiting their linkages rather than focusing on the development of individual resources. Moreover, as the value creation model is adjusted under various conditions, top management in banks, therefore, are expected to continue to learn from the interactions of intangibles and tangibles. This creates opportunities to identify and develop key sources of competitive advantage in their bank, and thereby set up a coherent strategy to search for a robust combination of intangibles and tangibles in response to conditional changes (Holland, 2010).

Both bank and analyst interviewees argued that in order to manage intangibles more effectively, bank managers should develop appropriate intangible measurements. However, measurement alone is not enough. The interviewees recognised that improving the overall portfolio of information sources and their interactions were critical to the quality of their decisions. Improvement in quantitative measures, along 
with qualitative measures, were required to improve the overall information supply and to create a more effective dialogue and argument within management teams (and analyst teams) for more effective internal decision making.

It was found that the case institutions can be divided into three groups with regard to their intangible measurement and evaluation experience, as shown in Figure 4. The first group in the sample has developed quantitative metrics for most of the key intangible elements across all categories of intangibles, and has also started to conduct internal statistical analyses to examine the interactions among intangibles. The second group of banks has a mature measurement framework in place. They have developed quantitative metrics for some intangible elements, but paid little attention to the interactions among metrics. Finally, managers who just talked about some intangible metrics and the measurement tools they used rather than systematically discussing their measurement systems were placed into the third group.

\section{Insert Figure 4 about here}

The three groups offer an example of how banks may vary in their management, measurement and qualitative evaluation of intangibles in their value creation process and business models. This variation may reflect differing views and uncertainty about the relative merits of measurement versus subjective evaluation in this area and about the nature of an optimal information system.

\subsection{Implications for banks' theoretical models}

The theoretical significance of the empirical insights in this paper is that they support development beyond conventional theoretical views where banks are interpreted as financial intermediaries that exist relative to markets because they reduce agency costs and transaction costs (Scholtens and van Wensveen, 2003).

The empirical insights reveal the need to understand ideas of a wider business model and the role of knowledge in innovation and competitive advantage, to fully understand how banks make their financial intermediation processes more effective and competitive. As Scholtens and van Wensveen (2003: 40) note;

“The contemporary theory of financial intermediation is not well-equipped to explain market dynamism... An amended theory is necessary to explain what was, is, and remains the essential function of banking and finance, how this function leads to new risk products, both for the intermediaries' own account ... and new risk products developed by them for the open market." 
The new theoretical narrative (Locke, 2001) corresponding to the above empirical findings can be briefly summarised as follows. Bank business models (IIRC, 2011) have knowledge intensive intangibles (or HC, SC and RC as in Meritum, 2002) that are rare, inimitable, difficult to copy sources of value (Barney, 1991). Bank business models also include core tangibles (e.g., financial assets, liabilities, technology) and tangible processes (e.g., risk management and intermediation, technological). These tangibles are common to specific bank models such as retail banking and are easily copied. In addition, the knowledge intensive intangibles are at the core of sustainable competitive advantage in business models, as noted in the resource based view of the firm (Barney, 1991). These integrated and combined intangibles and tangibles form bank business models (IIRC 2011) and value creation chains (Porter, 1985), which are the basis for banks to conduct risk management and financial intermediation in a more effective way than competitors, and this is expected to result in higher financial performance.

For example, the application of new intangibles in banking is expected to stabilise expected income, as better knowledge of intangibles, such as knowledge of customers and employees, can help banks better manage and forecast their transaction flow. It is also expected to improve the risk management and intermediation processes and to stabilise supply and demand, and costs and revenues, across market cycles.

In terms of the conventional narrative of finance theory and financial intermediation theory, such knowledge intensive banks provide the means to reduce agency costs and associated problems of information asymmetry, adverse selection and moral hazard. However, the empirical results reveal that the bank's primary aim was value creation. Reduction of agency costs and transaction costs was achieved as by-products of the main value creation purpose and activity, as suggested by Scholtens and van Wensween (2003). Thus, conventional finance and intermediation theory by themselves are inappropriate to explain the primary function, purpose, and behaviour of banks. They cannot explain the value creation process, the change process in banks, and emergence of new products and new transacting means. But these finance theory sources are important to explain the relationship between financial firms and markets once such change has occurred. Thus, current research requires both the established theory narrative and the new theory narrative to be connected in a coherent way in a much broader theoretical narrative. 
The paper can also be used to generate new theoretically based hypotheses for further research. For example, banks with the same tangibles (such as financial assets and liabilities) and same tangible processes (such as risk management and intermediation), but with intangibles with higher knowledge and sustainable competitive advantages (SCA), will be expected to have higher performance, and vice versa. The discussion of measurement and proxy issues in section 4 provides ideas on how to operationalize such hypotheses.

This paper has revealed the potential for developing theoretical models and generating new hypotheses by using empirical findings in the form of grounded theory and IC literature and combining them with conventional financial concepts of banks. Such theoretical development is required to support governments and regulators when demanding banks' careful management of bank IC in their bank models, to reduce individual bank risk and the likelihood of future crises.

\subsection{Theoretical discussion and systems implications for understanding bank models}

In the grounded theory, interactions and transformations occurred at many bank levels, and were not simple cause and effect relations between specific elements and performance, but reflected a complex interacting system. These complex interactions reflect a wider discussion in the literature (e.g., Cuganesan, 2005; Holland, 2004; Johanson et al., 2001; Murthy and Mouritsen, 2011). This view extends the theoretical narrative of the previous section.

\section{Interpreting the 'market for information' and social systems contexts}

The empirical observations can be interpreted from a systems perspective at bank organisational level. In Weick's terms $(1979,1995)$ bank organizing was a system of individual, team and organizational contexts, processes and behaviours (internal and external). In the case banks these included the bank knowledge intensive intangibles at firm (SC and RC) and team and individual levels (HC), and their interactions with each other and with tangible assets (financial, technology, etc.) and tangible decision processes (risk management, intermediation, etc.). These resources were integrated by the wider organisation system, the business model, and value creation aims around the concept of creating a sustainable competitive advantage (Barney, 1991).

This systems approach can be further developed by noting that the bank organisation is a sub-set of a larger social and market system and actively interacts 
with this larger system. In particular, we note that the case banks were actively involved in the communication (disclosure) of information (on bank business models and value creation processes) to markets and in the analysis of this information by market actors. This 'market for information' can be conceived of as the institutional means to connect corporate (bank) information supply activities to security market information demand activities (Keane, 1983). According to actor-network theory (Latour, 1987, 1993), the market consists of an alliance of actors (i.e., people and firms, such as bank managers, analysts and fund managers) who are involved in the invention, construction, distribution, performance and usage of information about companies such as banks. Major interactions or interrelations arise between people and other elements, such as in bank value creation processes, information production and exchange processes, and regular transactions between parties. Bank managers and analysts operate at the heart of this market. The external networks are important parts of social systems and means by which 'social forces' operate on these actors.

Holland et al. (2012) argue that ideas from 'sociology of finance' can be used to interpret the wider social context. For example, Henningsson (2009), using Luhmann (1995) and Fuchs (2001), has argued that people are a part of many different social systems and are therefore influenced by different logics. He proposes that fund managers and others create their own collective stories of different firms (such as banks) as well as of the functioning of the financial market. These stories evolve as a result of experience but are also strongly affected by social forces (Fuchs, 2001; Luhmann, 1995), and guide actors in the market for information, and stock and bond markets when they interpret (bank) information. In this way banks, analysts, fund managers, customers and others become limited by their own social blindness and knowledge creation may be blocked which makes it hard to understand new emerging phenomena like new IC use in changing business models in banks (Holland, 2010). As a result, differential knowledge creation and states can occur across these actors and banking firms due to such barriers.

A key social force in forming (and mis(in)forming) bank and other financial actors' ideas has been 'performativity'. Performativity has many aspects and includes situations where theoretical models become tools used by market actors, where this can modify economic processes, and whereby these processes become more like the theoretical models (Mackenzie, 2006). Performativity pressures are at work in the 'market for information' and stock markets. Ideas grounded in financial theory, about 
efficient markets, rational agents and information asymmetry, and asset pricing have dominated thinking about such markets, and about their 'efficiency' in assimilating information, in risk pricing and the valuation of companies such as banks. Bank dominated market processes became larger and much more active as a result of these theoretical views (Turner, 2009; Holland, 2010). Actors in these markets have operated on the assumptions in these theories or by their performative aspect, as noted by Vollmer et al. (2009). This in contrast to the non-use or ignorance of established and empirically tested risk management and intermediation concepts by failing bankers during the 2007 crisis (Holland, 2010).

We can also note that issues of 'culture' play a role in the social forces in financial networks, in communication problems and in resistance to change. Differences between a company's culture and that of the financial market has been identified as a cause of communication difficulties between them (Holland and Johanson, 2003; Henningsson, 2009). Banks and other financial firms have in part, 'overcome' these problems in information and stock markets by use of social or relational capital such as reputation in selected sub-networks of these markets (Holland, 2005, 2006). The uncritical performativity aspect of established theories has combined with social or reputational variables to create a climate of confidence in markets and bank participants to allow active transacting and communications to occur.

\section{Illustration of social forces}

The role of the social context on bank IC information disclosure, and on analysts' use of this information, and their dependence on the social system within which they are operating, can be illustrated by several examples from the empirical findings from this study.

As discussed in section 4, measurement and communication problems and differences between bankers and analysts were noted. These correspond to Henningsson's (2009) view that external observers such as analysts and fund managers are 'cultured observers' of companies (such as banks) and their IC information. They are influenced by social forces when they observe IC information. Social logics about their own host firm, the market price, and the agenda around certain banks, play a role in the subjective and social construction of ideas and information about bank IC. Managers in banks can also be seen as 'cultured observers' of their own value creation and disclosure processes, and of the external 
processes of analysts and fund managers (such as analysis, action, and bank reputation construction). Differences in these social logics (for managers in the bank, and for sell side analysts) and in the nature of their aims, specialist tasks and decision processes play a role in the differing viewpoints about business models, measurement, links to performance outcomes and communication gaps.

These social forces and the other factors above also played a role in their differing views on the problems of quantitative measurement of intangibles and preferences for qualitative measures. Managers were closer to the IC and value creation phenomena and thus in a privileged position to assess the credibility of such measures and their role in decision making. Analysts operated in an external world where they had to demonstrate analytic and numeric skills and could not risk their reputation here. They have wealth and information access incentives to bias their own IC and numerical disclosure outputs to match client and relationship company needs and to maintain their reputation. This bias and impression management corresponds to research by Chan et al. (2007), Mehran and Stulz (2007), Abhayawansa and Abeysekera (2009), and Abhayawansa and Guthrie (2012). This behaviour may be best controlled through improvements in bank modelling and enhanced bank disclosure of IC information. It was not clear from the data how these factors interacted to influence measurement, links to performance outcomes, and disclosure, and this must be the focus of further research. However, Figure 3 illustrates that the processes were distinct and led to different behaviours and outcomes.

This paper also indicates that analysts compensated for some of the problems of using and making sense of bank IC information, by conducting their analyses within wider information market contexts and processes. Their analyses of bank IC and its role in the bank's value creation process occurred in related contexts of each analyst's own personal knowledge, skills and capabilities, as well as the IC of the analyst's firm. Their analyses and sense making also occurred in the wider professional network context of many analysts and their shared knowledge, consensus analysis/forecast for banks, incentives for disclosure and analyst rankings. Finally, it also occurred within a wider information network of many other information-production professionals, and many information users. The dynamic character of this information market network was demonstrated by everyday interactions. It was also shown by learning and change in the bank, driving learning by the analysts (and by implication by others in the network) about bank IC and its changing role in bank value creation and value. Banks 
also compensated for some of the problems of disclosing IC information by conducting disclosure in such wider social systems of in public and private networks (Holland, 2005).

\section{Improving network actor understanding of bank business models}

The above are examples of Henningsson's (2009) argument that social groups in the world of finance, including bank management, bank analysts and investors, develop and are constrained by their own social environments, collective ideas and opinions that are stable and hard to change over time.

This paper argues that improvements in bank business models and a broader and matching dynamic theory narrative of banks and market, as discussed in the previous section, are a part of the solution to such problems. The creation of common and public knowledge about bank models, the role of IC, how banks change over time, how their models are empirically tested, and the creation of new bank theory closely matched to this phenomenon, may be one of the means to bring together these different social systems and their shared and differing perceptions, social logics and understandings of the core functions and roles of banks and markets. These are partial means to reduce the shared social blindness and untested narratives concerning new bank IC and business models. They are also partial means to ensure that collective stories are more grounded than those used in the recent past and more open to collective and explicit criticism and debate. This is the basis for a more 'reflexive performativity' based on theoretical models and empirical results that more fully reflect economic phenomena rather than creating them. 'Reflexive performativity' is interpreted as including situations where new and empirically tested theoretical models and literature (of, for example, intellectual capital and bank value creation) become tools used by many market actors (e.g., bank analysts) and where this can be used to modify (information market and stock) market processes in a more open, and public manner. The danger here is that the new theoretical and empirical narrative could again create new conditions of unthinking or convenient 'performativity' at some point in the future. Hence, a more critical and sceptical stance is required to the narrative. This may best be secured by a wider understanding of the social systems theory and ideas of 'performativity' discussed here. This requires a further extension to the theoretical narrative to include these ideas to create a more critical and reflexive 'performativity'. Thus, the development of bank models within an awareness of social 
forces and logics is required. This is required of business models and theoretical models. In the latter case those historic models derived from academic generated theory and literature, have proved to be the source of dogmatism and contributed to systemic risk (Turner, 2009). The approach developed in this paper is one possible way to ensure that the social forces, noted by Henningsson (2009) affect the behavior and actions of finance network actors (especially academics and practitioners) in more informed, critical and publicly open manner. Cultural barriers to communication could be reduced by such wider shared understandings. This provides an opportunity to improve awareness of social systems and their implications for finance both amongst academics and practitioners.

In more practical terms, new bank models would be a new basis for improving the public and private interpretation and discussion of bank risks and performance. There is also a need for banks to disclose more information about intangibles. Improving the interpretive model and its information requirements is necessary for analysts, fund managers and other actors (e.g., bank rating agencies), and for wider processes in the market for information. For example, Beattie and Thomson (2010) have conducted a study of intellectual capital reporting, and raised several questions regarding IC disclosure, such as whether meaningful and effective regulation is desirable, and at what level it should operate. They argue that there is an opportunity to "investigate whether a set of industry-specific standardised metrics can be developed and their disclosure regulated" (Beattie and Thomson, 2010: 140). This paper shows that there appears to be a need for bank industry-specific reporting standards or guidelines from both internal managers' and external analysts' perspectives and from wider information market perspectives. Appropriate standards, based on explicit bank models (business and theoretical) for each major bank type and its specialised use of IC, could encourage banks to disclose more and consistent intangible metrics and reduce the problem of information manipulation, thereby provide reliable and comparable information to analysts for bank valuation.

\section{Conclusions}

This paper provides a new way of rethinking banking models by using qualitative research on intangibles. Based on interviews with bank managers and analysts, a grounded theory of bank intangibles is generated, revealing how intangibles and tangible/financial resources interact in the bank value creation process and actively 
respond to environmental changes. An appropriate combination and interaction of intangibles and tangible/financial resources provides the means to improve the processes of financial intermediation, information intermediation and risk management in banks. This grounded theory offers a novel insight into the banking business model and draws the attention to the increasingly important role that intangibles play in it. It suggests that existing bank business models should be further developed in a conceptually richer world of intangibles, knowledge and information.

The paper also offers opportunities for theoretical development. Compared with the extant banking literature that focuses heavily on tangible or financial resources, this paper shows how issues of knowledge and capabilities in banks and bankers can be related to conventional theoretical ideas in banking, such as intermediation, information problems and risk management. It suggests that the conventional information dimensions to these theoretical ideas can be expanded by including ideas of knowledge-based intangibles in banking from the IC literature. Moreover, the grounded theory generated here provides a means to improve intangible measurement and disclosure, which provides an opportunity for academic researchers to further investigate the role of intangibles in the value creation process using quantitative techniques.

Furthermore, this paper argues that social systems theory and concepts of 'performativity' are relevant to understanding the wider context. The creation of common and public knowledge about bank business models, and the creation of new bank theory closely matched to this phenomenon may be one of the means to bring together different social systems and their shared and differing social logics and understandings of banks and markets. If this is combined with a systems perspective by these bank and network actors, this is the basis for a more 'critical and reflexive performativity' based on theoretical models and empirical results that more fully reflect economic phenomena rather than creating them. Practitioners can develop new business models which are based on their own learning and strategic aims. They can also consider developing them in the context of empirical field research on business models (or grounded theory), new matching theoretical developments, and an understanding of the impact of social forces and logics on their understandings and actions.

This is related to Hopwood's (2009) editorial in Accounting, Organization and Society where he argued for more critical studies of financial markets. Vollmer et al. 
(2009) in the same issue suggested that a closer engagement with sociology would benefit not only studies of behaviour in financial markets but also studies in accounting.

There is a need for further studies of IC, addressing corporate IC value creation, business and theory models, disclosure practise as well as information market behaviour. However, we would argue that the present explorative study on banks supports the proposal that further studies of IC would gain from exploiting recent developments in the sociology of finance, in particular concepts of organisational and social systems, performativity and cultural barriers, in interpreting their results. 


\section{References}

Abhayawansa, S. and Abeysekera, I. (2009), “Intellectual capital disclosure from sellside analyst perspective”, Journal of Intellectual Capital, Vol. 10 No 2, pp. 294306.

Abhayawansa, S. and Guthrie, J. (2012), "Intellectual capital information and stock recommendations: Impression management?”, Journal of Intellectual Capital, Vol. 13 No 3, pp. 398-415.

Athanasoglou, P. P. A., Brissimis, N. S. and Delis, M. D. (2008), "Bank-specific, industry-specific and macroeconomic determinants of bank profitability”, Journal of International Financial Markets, Institutions and Money, Vol. 18 No.2, pp. 121136.

Barney, J. (1991), “Firm resources and sustained competitive advantage”, Journal of Management, Vol. 17 No. 1, pp. 99-120.

Beattie, V., Fearnley, S. and Brandt, R. (2001), Behind Closed Doors: What Company Audit is Really About, Palgrave, Basingstoke, Hampshire.

Beattie, V. and Thomson, S. J. (2007), "Lifting the lid on the use of content analysis to investigate intellectual capital disclosure”, Accounting Forum, Vol. 31 No. 2, pp. 129-163.

Beattie, V. and Thomson, S. J. (2010), Intellectual Capital Reporting: Academic Utopia or Corporate Reality in a Brave New World? ICAS Research Report, The Institute of Chartered Accountants of Scotland, Edinburgh.

Benston, G. J. and Smith, C. W. (1976), “A transactions cost approach to the theory of financial intermediation”, The Journal of Finance, Vol. 31 No. 2, pp. 215-231.

Berger, A. N., Molyneux, P. and Wilson, J. O. S. (2010), "Banking: an overview”, In Berger, A. N., Molyneux, P. and Wilson, J. O. S. (Eds.), The Oxford Handbook of Banking, Oxford University Press, Oxford, pp. 1-36.

Campbell, D. and Slack, R. (2008), Analysts' perspectives on the materiality of voluntary narratives in annual reports, ACCA Research Report 104, The Association of Chartered Certified Accountants, London.

Chan, L. K. C., Karceski, J. and Lakonishok, J. (2007), “Analysts’ conflicts of interest and biases in earnings forecasts", Journal of Financial \& Quantitative Analysis, Vol. 42 No. 4, pp. 893-913.

Colgate, M. R. and Danaher, P. J. (2000), "Implementing a customer relationship strategy: the asymmetric of poor versus excellent execution”, Journal of the Academy of Marketing Science, Vol. 28 No.3, pp. 375-387. 
Cuganesan, S. (2005), "Intellectual capital-in-action and value creation: a case study of knowledge transformations in an innovation project”, Journal of Intellectual Capital, Vol. 6 No. 3, pp. 357-373.

Dey, I. (1999), Grounding Grounded Theory: Guidelines for Qualitative Inquiry, Academic Press, San Diego, CA.

Diamond, D. W. (1984), "Financial intermediation and delegated monitoring”, Review of Economic Studies, Vol. 51 No. 166, pp. 393-414.

Dietrich, A. and Wanzenried, G. (2011), "Determinants of bank profitability before and during the crisis: evidence from Switzerland", Journal of International Financial Markets, Institutions and Money, Vol. 21 No. 3, pp. 307-327.

Fahy, J. (2000), “The resource-based view of the firm: some stumbling blocks on the road to understanding sustainable competitive advantage”, Journal of European Industrial Training, Vol. 24 No. 2/3/4, pp. 94-104.

Fuchs, S. (2001), Against Essentialism: A Theory of Culture and Society, Harvard University Press, London.

Henningsson, J. (2009), “Fund managers as cultured observers”, Qualitative Research in Financial Markets, Vol. 1 No. 1, pp. 27-45.

Holland, J. (2004), Corporate Intangibles, Value Relevance and Disclosure Content, ICAS Research Report, The Institute of Charted Accountants of Scotland, Edinburgh.

Holland, J B, (2005), “A grounded theory of corporate disclosure”, Accounting and Business Research, Vol. 35 No.3, pp. 249-267.

Holland, J. (2006), "Fund management, intellectual capital, intangibles and private disclosure”, Managerial Finance, Vol. 32 No. 4, pp. 277-316.

Holland, J. (2009), "Looking behind the veil: invisible corporate intangibles, stories, structure and the contextual information content of disclosure”, Qualitative Research in Financial Markets, Vol. 1 No. 3, pp. 152-187.

Holland, J. (2010), "Banks, knowledge and crisis: a case of knowledge and learning failure”, Journal of Financial Regulation and Compliance, Vol. 18 No. 2, pp. 87105.

Holland, J., Henningsson, J., Johanson, U., Koga, C. and Sakakibara, S. (2012), "Use of IC information in Japanese financial firms”, Journal of Intellectual Capital, Vol. 13 No. 4, pp.562-581.

Holland, J. and Johanson, U. (2003), "Value relevant information on corporate intangibles - creation, use, and barriers in capital markets - 'Between a rock and a hard place’”, Journal of Intellectual Capital, Vol. 4 No 4, pp. 465-486. 
Hopwood, A. (2009), "Exploring the interface between accounting and finance" Accounting, Organizations and Society, Vol. 34 No. 5, pp. 549-550.

IIRC (2011), International integrated reporting initiative - towards integrated reporting, communicating value in the 21st century, discussion paper, The International Integrated Reporting Committee, 12th September 2011.

Johanson, U., Martensson, M. and Skoog, M. (2001), "Measuring to understand intangible performance drivers”, The European Accounting Review, Vol. 10 No. 3, pp. 407-437.

Keane, S. (1983), Stock Market Efficiency - Theory, Evidence, Implications, 1st edition, Philip Allan Publisher Ltd, Oxford.

Kristandl, G. and Bontis, N. (2007), “Constructing a definition for intangibles using the resource based view of the firm”, Management Decision, Vol. 45 No. 9, pp. 1510-1524.

Latour, B. (1987), Science in Action: How to Follow Scientists and Engineers through Society, Harvard University Press, Cambridge.

Latour, B. (1993), We Have Never Been Modern (translated by C. Porter), Harvester Wheatsheaf, London.

Lev, B. (2001), Intangibles: Management, Measurement and Reporting, The Brookings Institution, Washington.

Locke, K. D. (2001), Grounded Theory in Management Research, Sage Publications, London.

Luhmann, N. (1995), Social Systems, Stanford University Press, Stanford, California.

Mackenzie, D. (2006), "Is economics performative? Option theory and the construction of derivatives markets”, Journal of the History of Economic Thought, Vol. 28 No.1, pp. 29-55

Mackenzie, D. and Millo, Y. (2003), "Negotiating a market, performing theory: The historical sociology of a financial derivatives exchange”, American Journal of Sociology, Vol. 109, pp. 107-145.

Marr, B., Gray, D. and Neely, A. (2003), "Why do firms measure their intellectual capital?” Journal of Intellectual Capital, Vol. 4 No. 4, pp. 441-464.

Mehran, H. and Stulz, R. M. (2007), “The economics of conflicts of interest in financial institutions”, Journal of Financial Economics, Vol. 85 No. 2, pp. 267-296.

Meritum, (2002), Guidelines for Managing and Reporting on Intangibles (Intellectual Capital Report), TSER Programme, MERITUM, Tucson, AZ. 
Mouritsen, J., Bukh, P. N., Larsen, H. T. and Johansen, M. R. (2002), "Developing and managing knowledge through intellectual capital statements", Journal of Intellectual Capital, Vol. 3 No.1, pp. 10-29.

Murthy, V. and Mouritsen, J. (2011), "The Performance of intellectual capital: relationships between intellectual and financial capital in a bank”, Accounting, Auditing \& Accountability Journal, Vol. 24 No. 5, pp. 622-646.

Pandit, N. R. (1996), “The creation of theory: a recent application of the grounded theory method”, The Qualitative Report, Vol. 2 No. 4, pp. 1-20.

Parker, L. D. and Roffey, B. H. (1997), "Back to the drawing board: revisiting grounded theory and the everyday accountant's and manager's reality”, Accounting, Auditing \& Accountability Journal, Vol. 10 No. 2, pp. 212-247.

Porter M (1985), Competitive Advantage: Creating and Sustaining Superior Performance, The Free Press, New York.

Reed, K. K., Lubatkin, M. and Srinivasan, N. (2006), "Proposing and testing an intellectual capital-based view of the firm”, Journal of Management Studies, Vol. 43 No. 4, pp. 867-893.

Scholtens, B. and van Wensveen, D. (2000), "A critique on the theory of financial intermediation”, Journal of Banking and Finance, Vol. 24 No. 8, pp. 1243-1251.

Scholtens, B. and van Wensveen, D. (2003), “The theory of financial intermediation: an essay of what it does (not) explain”, discussion paper, The European Money and Finance Forum, Vienna, 2003.

Strauss, A. and Corbin, J. (1998), Basic of Qualitative Research: Techniques and Procedures for Developing Grounded Theory, $2^{\text {nd }}$ Edition, Sage Publications, Thousand Oaks, CA.

Suddaby, R. (2006), "From the editors: what grounded theory is not", Academy of Management Journal, Vol. 49 No. 4, pp. 633-642.

Teece, D. J. (2007), "Explicating dynamic capabilities: the nature and microfoundations of (sustainable) enterprise performance”, Strategic Management Journal, Vol. 28 No. 13, pp. 1319-1350.

Teece, D. J., Pisano, G and Shuen, A. (1997), "Dynamic capabilities and strategic management”, Strategic Management Journal, Vol. 18 No. 7, pp. 509-533.

Turner A. (2009), Chairman, FSA, speech for, The Economist's Inaugural City Lecture, LSE, $21^{\text {st }}$ January 2009.

Vollmer, H., Mennicken, A., and Preda, A. (2009), "Tracking the numbers across accounting and finance, organizations and markets”, Accounting, Organizations and Society, Vol. 34 No 5, pp. 619-637. 
Watkins, T. (2000), Marketing Strategies in Retail Banks: Current Trends and Future Prospects, LLP Professional Publishing, London.

Weick, K. E. (1979), The Social Psychology of Organizing, 2nd edition, AddisonWesley, Redding, MA.

Weick, K. E. (1995), Sensemaking in Organizations. Sage, Thousand Oaks, CA.

Wilson, J. O. S., Casu, B., Girardone, C. and Molyneux, P. (2010), "Emerging themes in banking: recent literature and directions for future research", The British Accounting Review, Vol. 42 No. 3, pp. 153-169. 
Table 1: Examples of interactions

\begin{tabular}{|c|c|c|}
\hline & Case ref. & Concepts and interactions \\
\hline \multirow[t]{4}{*}{$\begin{array}{l}\text { Intra- } \\
\text { category } \\
\text { interactions }\end{array}$} & B3, B8 & $\begin{array}{l}\text { Training investment (employee level HC investment) } \rightarrow \\
\text { Employee satisfaction or loyalty (employee level HC } \\
\text { resource) }\end{array}$ \\
\hline & B11 & $\begin{array}{l}\text { IT investment (SC investment) } \rightarrow \text { Improved internal system } \\
\text { (SC resource) }\end{array}$ \\
\hline & B7, A11 & $\begin{array}{l}\text { Marketing expenditures ( } \mathrm{RC} \text { investment) } \rightarrow \text { Customer } \\
\text { relationships ( } \mathrm{RC} \text { resource) }\end{array}$ \\
\hline & $\begin{array}{l}\text { B8, B11, } \\
\text { A10 }\end{array}$ & $\begin{array}{l}\text { Brand strength }(\mathrm{RC} \text { resource }) \rightarrow \text { Customer relationships }(\mathrm{RC} \\
\text { resource) }\end{array}$ \\
\hline \multirow{5}{*}{$\begin{array}{l}\text { Cross- } \\
\text { category } \\
\text { interactions }\end{array}$} & B10, A1, A6 & Top management $\mathrm{HC} \rightarrow$ Organisational culture $(\mathrm{RC})$ \\
\hline & A4, B2 & $\begin{array}{l}\text { Top management } \mathrm{HC} \rightarrow \text { Customers' confidence with the } \\
\text { bank }(\mathrm{RC})\end{array}$ \\
\hline & $\begin{array}{l}\text { B1, B4, B5, } \\
\text { B7, B9 }\end{array}$ & $\begin{array}{l}\text { Employee retention or employee quality (employee level HC) } \\
\rightarrow \text { Customer satisfaction or relationships (RC) }\end{array}$ \\
\hline & B4, B7 & $\begin{array}{l}\text { Brand strength }(\mathrm{RC}) \rightarrow \text { Employee engagement (employee } \\
\text { level HC) }\end{array}$ \\
\hline & B1, B7 & $\begin{array}{l}\text { Internal supporting system }(\mathrm{SC}) \rightarrow \text { Employee retention } \\
\text { (employee level HC) }\end{array}$ \\
\hline \multirow{6}{*}{$\begin{array}{l}\text { Internal } \\
\text { bank firm } \\
\text { network } \\
\text { interactions }\end{array}$} & A4, A7 & $\begin{array}{l}\text { Brand strength }(\mathrm{RC}) \rightarrow \text { Taking deposits (financial } \\
\text { intermediation process) }\end{array}$ \\
\hline & B3, A1, A2 & $\begin{array}{l}\text { Cross-selling (RC) } \rightarrow \text { Increasing loans (financial } \\
\text { intermediation process) }\end{array}$ \\
\hline & A2, A11 & $\begin{array}{l}\text { Brand strength }(\mathrm{RC}) \rightarrow \text { Lower cost of deposits (financial } \\
\text { intermediation process) }\end{array}$ \\
\hline & B1, B6, B8 & $\begin{array}{l}\text { Customer relationships (RC) } \rightarrow \text { Reduction of costs (financial } \\
\text { intermediation process) }\end{array}$ \\
\hline & B2 & $\begin{array}{l}\text { Customer confidence with the bank }(\mathrm{RC}) \rightarrow \text { Reduction of } \\
\text { deposit withdrawal risk (risk management) }\end{array}$ \\
\hline & A6, B4 & Top management $\mathrm{HC} \rightarrow$ Risk management \\
\hline
\end{tabular}

Notes: A1 to A12 refer to interviews with bank analysts, and B1 to B11 refer to interviews with managers in financial institutions. HC refers to human capital, SC to structural capital and RC to relational capital. 
Figure 1: The grounded theory of bank intangibles

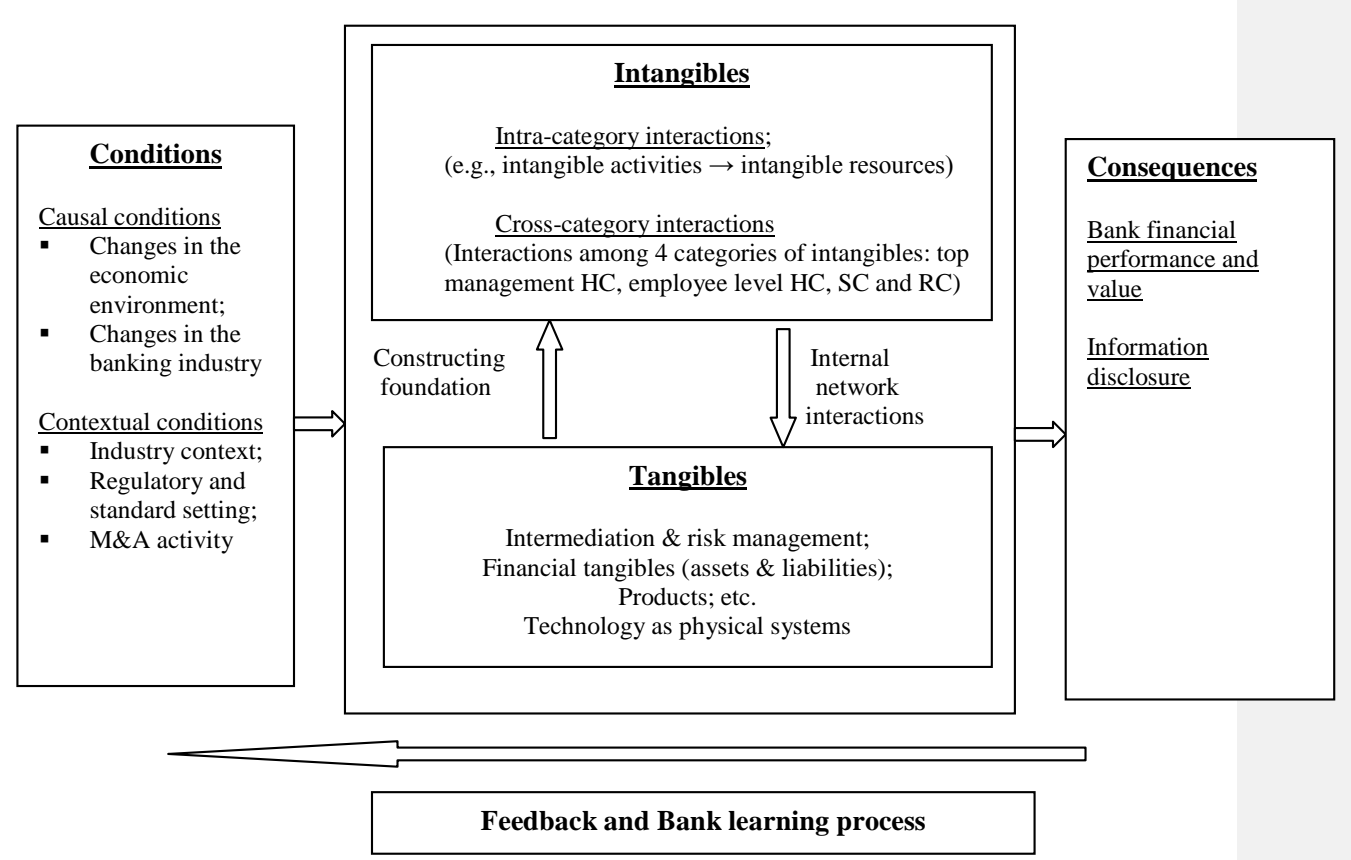

Notes: HC refers to human capital, SC to structural capital and RC to relational capital. 
Figure 2: An example of cross-category interactions

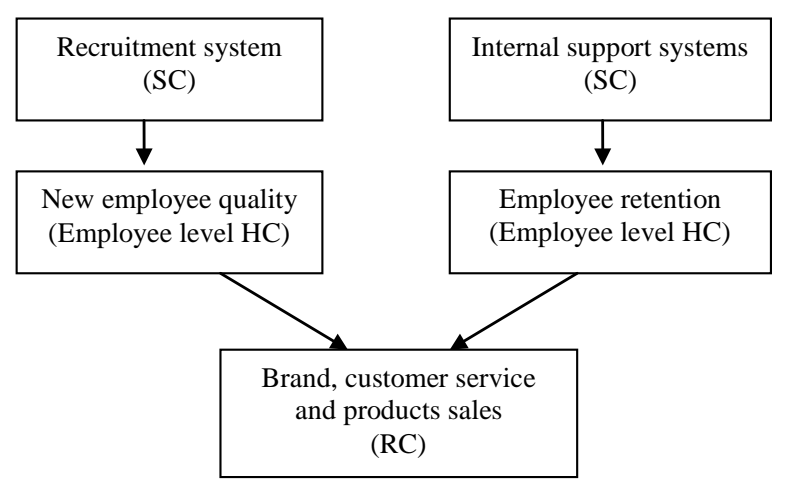

Notes: HC refers to human capital, SC to structural capital and RC to relational capital. 
Figure 3: The processes of intangible measurement and disclosure from managers' and analysts' perspectives

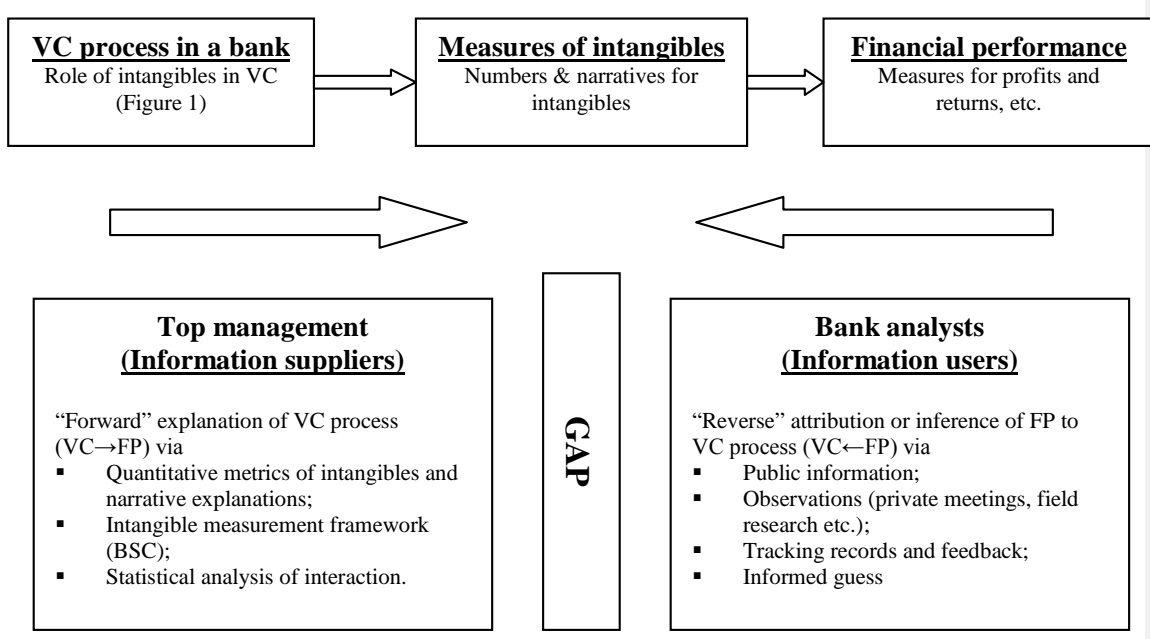

Notes: VC refers to value creation, FP to financial performance and BSC to the Balanced Scorecard. 
Figure 4: Intangible measurements in the case institutions

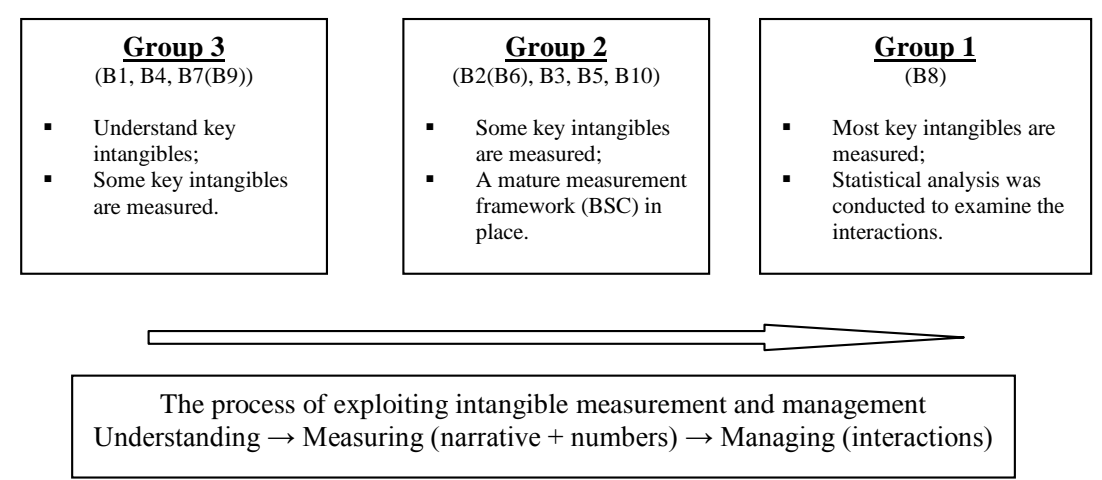

Notes: Manager B2 and managers in interview B6 worked in the same bank but in different positions, and managers B7 and B9 worked in the same bank but in different business segments. 